\title{
DEMOKRATISASI
}

\section{(Ikhtiar Budaya dan Nilai Menuju Demokrasi)}

\author{
Oleh Ibrahim $^{1}$
}

\section{Pengantar}

Term demokrasi dan demokratisasi kadang rancu. Lebih sering lagi adalah seseorang mengkhotbakan demokratisasi dengan basis pijakan identitas tertentu sehingga ia sebetulnya berteriak atas nama demokrasi untuk sesuatu yang sifatnya tidak demokratis. Kerapkali juga, seseorang berdiri dalam bungkus kediktatoran, namun dengan sedikit pengertian sempit mengenai demokrasi, ia menganggap dirinya berbicara secara demokratis.

Demokrasi adalah budaya dan nilai. Bukan baskom, yang didalamnya kita masuk dan bergoyang-goyang. Demokrasi adalah budaya hidup dan nilai yang untuk menikmatinya harus diperjuangkan secara sadar. Tulisan ini memberi pemahaman dasar mengenai konsep dasar demokrasi, corak perjuangannya, dan varian-varian yang melekat didalamnya.

\section{Pembahasan}

Demokrasi, dewasa ini, adalah bentuk pemerintahan yang paling banyak dianut di seluruh dunia, sekalipun sebenarnya demokrasi bukanlah bentuk baru dalam sistem pemerintahan. Meski demikian, relativitas bentuk demokrasi mengalami perluasaan dan penyempitan dalam tataran aktualisasinya. Oleh karena itu, diskursus mengenai bentuk ideal dari demokrasi tidaklah pernah final karena sangat kontekstual dan relatif.

Amerika Serikat yang kerap dijuluki sebagai kampiun demokrasi pun tetap berhadapan dengan fakta bahwa terdapat segregasi yang tajam

\footnotetext{
${ }^{1}$ Ibrahim adalah Dosen pada Fakultas Hukum dan Ilmu Sosial Universitas Bangka Belitung, meminati isu politik, demokrasi, dan kebijakan publik.
} 
antara kelompok kulit hitam dan kelompok kulit putih, yang sekalipun secara legal sudah termaktub dalam deklarasi kesetaraan, tetap saja hingga kini berhadapan dengan konflik rasis. Di sana, kelompok moderat dan konservatif yang lahir dari pemahaman yang agak berbeda dalam soal implementasi agama pun sebenarnya hingga kini tetap menjadi masalah yang tidak dapat dianggap remeh. Demokrasi dalam konteks negeri ini pun tetap mengalami varian dalam implementasinya. Di negara-negara komunis, demokrasi dipahami berkebalikan dari semangat liberalisme. Justru bagi masyarakat komunis, demokrasi adalah ketika warga negara mendapatkan haknya secara setara, terutama dalam hal kepemilikan ekonomi. Negaralah yang kemudian harus bertanggung jawab dalam mewujudkan demokrasi ekonomi tersebut. Di Indonesia, kecendrungan adopsi nilai-nilai demokrasi dari dua kutub besar yang beraliran sosialisme dan liberalisme tak terelakkan.

Itulah sebabnya, Melvin (2002) mengatakan bahwa demokrasi adalah sistem yang bertumbuh-berkembang dan setiap bangsa harus menata pemerintahannya dengan berpijak pada sejarah dan kebudayaannya sendiri. Hanya saja, dalam bahasan demokrasi, ada nilai-nilai dasar yang menjadi narasi umum.

Setidaknya ada tiga hal utama dalam substansi demokrasi politik, di luar itu adalah pengembangan lain sepanjang relevan. Tiga hal tersebut menurut Sorensen $(2003)^{2}$ adalah Kompetisi, Partisipasi, dan Kebebasan Politik dan Sipil ${ }^{3}$. Kompetisi terjadi secara luas antara individu dan kelompok-kelompok organisasi dan seluruh kekuasaan pemerintah, dalam jangka waktu yang teratur, dan meniadakan penggunaan kekerasaan. Partisipasi politik yang inklusif dalam sukses kepemimpinan dan pada

2 George Sorensen, 2003. Hal.19-20.

3 Imam Hidajat (2009) mengatakan bahwa indikator adanya demokrasi adalah (a) adanya partisipasi masyarakat dalam Pemilu (b) adanya kompetensi elit politik dalam rekrutmen secara terbuka (c) rotasi jabatan secara regular (d) pembagian kewenangan pusat dan daerah (e) sistem pengawasan yang efektif. Sekalipun Imam Hidajat mengabaikan fakta bahwa banyak negara yang menerapkan sistem demokrasi semu, dalam arti kata sebagai selubung bagi politik diplomasi. Pemilu di bawah rezim Junta Myanmar adalah sebuah bentuk demokrasi yang tidak demokratis. 
akhirnya pengambilan kebijakan. Sementara kebebasan politik dan sipil dimaknai sebagai kebebasan berpendapat, pers yang bebas, dan kehendak untuk mendirikan organisasi untuk berserikat yang bertujuan untuk menjamin integritas partisipasi dan kompetisi politik.

Sementara itu, Melvin (2002) ${ }^{4}$ mengatakan bahwa ada 11 prinsip dasar dalam demokrasi, yakni Prinsip pemerintahan berdasarkan konstitusi, Pemilihan Umum yang demokratis, Federalisme, Pemerintahan negara bagian dan lokal, Pembuatan Undang-Undang, Sistem peradilan yang independen, Kekuasaan lembaga kepresidenan, Peran media yang bebas, Peran kelompok-kelompok kepentingan, Hak masyarakat untuk tahu, Melindungi hak-hak minoritas, dan Kontrol sipil atas militer.

Demokrasi biasanya bertumbuh dengan diawali oleh proses revolusi atas pemerintahan yang sifatnya diktator, mengalami proses transisi, lalu menuju proses konsolidasi. Proses demokratisasi ini berjalan lambat, kompleks, dan melibatkan berbagai fase ${ }^{5}$. Purwo Santoso $(2010)^{6}$ mengisyaratkan bahwa demokratisasi memang harus dilampaui dengan sejumlah letupan-letupan konflik besar dan biasanya masih menyisakan letupan-letupan kecil setelahnya.

Demokratisasi berkembang dengan sejumlah prasyarat penting. Sorensen $^{7}$ mengatakan bahwa ada empat prakondisi bagi perkembangan demokrasi. Pertama, modernisasi dan kesejahteraan akan menjadi iklim kondusif bagi perkembangan demokrasi. Lipset dan Dahl ${ }^{8}$ menyebutkan bahwa semakin sejahtera sebuah negara, maka potensi perkembangan demokrasi akan semakin baik. Kedua, faktor budaya politik yang menyangkut sistem nilai dan keyakinan, yang menjelaskan konteks makna

\footnotetext{
${ }^{4}$ Melvin J. Urofsky, 2002. Hal. 31-41.

5 Melvin J. Urofsky (2002) mengatakan bahwa demokrasi mungkin memang merupakan pemerintahan yang paling rumit dan sulit karena melibatkan banyak ketegangan dan pertentangan, dan mensyaratkan ketekunan dalam prosesnya. Meski demikian, demokrasi yang berhasil akan membawa implikasi pada legitimasi yang kuat.

${ }^{6}$ Makalah 'Dialog Jakarta-Papua: Sebuah Keniscayaan?' Yang diselenggarakan oleh Imparsial, Yogyakarta, 21 Oktober 2010.

${ }_{8}^{7}$ George Sorensen, 2003. Hal. 41.46.

${ }^{8}$ Dalam ibid.
} 
dan tindakan. Ketiga, struktur sosial masyarakat, yakni kelas dan kelompok tertentu perlu diidentifikasi. Kecenderungan menunjukkan bahwa demokrasi membutuhkan kelas penduduk kota yang besar dan independen sebagai kunci dari pengembangan demokrasi. Keempat, faktor eksternal, yakni faktor ekonomi, politik ideologi dan elemen-elemen lain yang merupakan konteks internasional dari proses yang terjadi di suatu negara.

Satu hal yang harus diperhatikan adalah bahwa demokrasi bukanlah sesuatu yang given. Sorensen ${ }^{9}$ menyebutkan bahwa pengembangan demokrasi membutuhkan individu, kelompok, dan aktoraktor sosial untuk memperjuangkannya.

Dalam proses perjuangan mewujudkan demokrasi, tahapan yang biasanya dilewati adalah tahapan persiapan (runtuhnya rezim nondemokratis), tahapan keputusan (mulai tertanamnya tatanan demokratis), dan tahapan konsolidasi (demokrasi menjadi budaya politik $)^{10}$. Tahapan persiapan adalah tahapan perjuangan yang biasanya melibatkan pertentangan tajam antara rezim nondemokratis dengan rezim yang berjuang untuk demokrasi ${ }^{11}$. Tahapan keputusan adalah kesepakatan antar tokoh politik untuk melembagakan demokrasi dalam pemerintahan. Koalisi menjadi penting dalam tahapan ini karena pengalaman banyak negara pasca tumbangnya rezim otoriter dihadapkan dengan posisi konflik antarfaksi. Revolusi Perancis pada mulanya tidak melahirkan kondisi yang baik bagi perkembangan demokrasi dan cenderung terjebak dalam konflik antar elit yang menyebabkan peperangan panjang. Sementara tahapan konsolidasi adalah proses dimana demokrasi menjadi sebuah budaya politik. $^{12}$

Sorensen kemudian memprediksi bahwa akan ada dua bentuk akhir yang kemungkinan akan tercipta dalam demokratisasi, yakni tren positif

\footnotetext{
${ }^{9}$ Ibid. Hal.48.

${ }_{11}^{10}$ Lihat dalam Larry Diamond (2003) dan Georg Sorensen (2003).

11 Richard M. Ketchum (Ed), 2004, mengatakan bahwa demokrasi sejati adalah bentuk pertentangan dari kediktatoran.

12 Goerge Sorensen, 2003. Hal. 70-81.
} 
berupa kemajuan demokrasi dari aras lokal, nasional, dan internasional. Bentuk ini akan menimbulkan perdamaian dan iklim kondusif bagi pembangunan di dunia Barat, sementara di dunia Timur akan ditandai dengan kemajuan di bidang ekonomi dan peningkatan standard kehidupan. Tren kedua adalah pembusukan demokrasi yang akan diawali dengan arogansi berbagai organisasi lintas negara, terjadinya ketimpangan ekonomi, dan krisis ekonomi melanda di negara-negara Timur. Kondisi ini diperparah oleh konflik etnis (juga religi). ${ }^{13}$

Oleh karena itu, Larry Diamond (2003) ${ }^{14}$ menganjurkan tiga tugas utama kelompok pro demokrasi dalam rangka terkonsolidasinya demokrasi. Tiga tugas utama tersebut adalah penguatan demokrasi, pelembagaan politik, dan kinerja rezim. Penguatan demokrasi terbentuk dengan penguatan struktur-struktur formal demokrasi menjadi lebih liberal, akuntabel, representatif, dan terjangkau. Sedangkan pelembagaan politik dilakukan dengan melindungi hak-hak rakyat, pengurangan penyalahgunaan hukum, sistem peradilan yang memiliki derajat koherensi, kapasitas, dan otonomi kelembagan yang tinggi. Sementara kinerja rezim bertanggung jawab untuk mengeluarkan kebijakan-kebijakan yang positif untuk membangun legitimasi politik yang kuat.

Purwo Santoso $(2009)^{15}$ mengatakan bahwa demokratisasi tidak hanya mensyaratkan penggalangan kekuatan, namun juga pencurahan kecerdasan. Bahkan pencurahan kekuatan itu harus dilakukan secara kolektif. Jika selama ini perjuangan mewujudkan demokrasi cenderung hanya berkutat soal hak dan perjuangan dalam mencapai hak tersebut, maka rute yang seharusnya dilalui sekarang adalah bercorak adversarial (secara berhadap-hadapan). Corak ini disebut dengan istilah actor-based. Meski demikian, corak actor-based selama ini cenderung melupakan dimensi struktural, yaitu kekuasaan dan kesejahteraan. Oleh karena itu,

\footnotetext{
${ }^{13}$ Ibid. Hal. 219-224.

${ }^{14}$ Larry Diamond, 2003. Hal. 93-95.

15 Makalah yang disampaikan dalam Intensive Course and Training on Human Right-Based Democracy 2009: Power, Welfare, and Democracy, Yogyakarta, 13-18 Desember 2009.
} 
dua hal utama, menyangkut kontrol atas kesewenang-wenangan negara dan pengembangan kesejahteraan, harus menjadi corak dari pengembangan demokratisasi.

Problem selanjutnya adalah bagaimana melakukan penilaian terhadap demokrasi ${ }^{16}$. Menurut Olle Tornquist \& Nicolaas Warouw $(2009)^{17}$, dalam rangka memahami dan menilai demokrasi di Indonesia, ada perangkat dasar yang harus dikembangkan (ketimbang merujuk pada IDEA $)^{18}$. Perangkat dasar tersebut adalah institusi, kehendak, dan kapasitas. Institusi demokratis biasanya dicirikan oleh (a) konstitusionalisme yang menyangkut kewarganegaraan, hukum, dan hak, (b) kedaulatan rakyat yang menyangkut Pemilu, representasi politik, daya tanggap dan akuntabilitas tata pemerintahan, (c) partisipasi warga negara yang menyangkut berbagai asosiasi, media, dunia akademisi, dan partisipasi langsung. Selain kelaziman di atas, kiranya juga perlu dimasukkan penilaian dalam institusi-institusi nonformal. Sedangkan menyangkut kehendak diidentifikasi dengan aktor-aktor demokrasi dan bagaimana para aktor ini memanfaatkan institusi demokrasi yang sudah ada. Pemanfaatan institusi demokrasi ini perlu ditelusuri mengarah kemana. Sementara berkaitan dengan kapasitas, penilaian ini harus mempertimbangkan beberapa faktor kunci yang berkaitan dengan kekuasaan, sumber daya, dan gerakan.

Dengan demikian, ada beberapa poin penting yang harus dicatat. Pertama bahwa demokrasi bukanlah bentuk baku, yang given. Keberadaannya harus diikhtiarkan secara sadar dan sistematis dengan melibatkan berbagai aktor yang sadar untuk mendistribusikan nilai-nilai

\footnotetext{
${ }^{16}$ Tadjuddin Noer dalam pengantar buku Demokrasi dan Demokratisasi (2003) mengatakan bahwa salah satu kesulitan mendasar dari proses evaluasi dan penilaian ini adalah kurang berminatnya para ilmuwan (politik) dalam mendiskusikan, menulis, dan meneliti persoalan demokratisasi. Bahkan Tadjuddin mengatakan bahwa ada kencendrungan bahwa ilmuwan lebih senang berbicara sebagai pengamat di berbagai media massa.

${ }^{17}$ Tulisan ini terdapat dalam Demokrasi di Atas Pasir (2009) yang merupakan catatan laporan Demos mengenai kemajuan dan kemunduran demokrasi di Indonesia. Bagian tulisan ini berbicara mengenai konsep dan metode yang digunakan.

${ }^{18}$ IDEA adalah Institute for Democracy and Electoral Assistance yang berpusat di Stockholm.
} 
demokratis. Mengandaikan demokrasi adalah sesuatu yang given adalah sebuah kemustahilan. Ketika nilai-nilai demokrasi bertumbuh, di sisi depan sudah menghadang para aktor yang tidak menyenangi penyebaran nilai-nilai demokratis tersebut. Bagaimanapun, demokrasi berpotensi membunuh kediktatoran, arogansi, dan kultur feodal. Itulah sebabnya, ketika kaum pro demokrasi bertumbuh, maka kalangan antidemokrasi juga sedang bekerja. Corak actor based di sini menemukan fungsinya sebagai ruang bagi pergumulan antar aktor yang sadar.

Oleh karenanya, ruang publik, menurut Habermas ${ }^{19}$ harus bersifat diskursif dan deliberatif. Diskursif bermakna keterbukaan terhadap perdebatan sehinggal putusan yang diambil haruslah merupakan rumusan baku dari hasil perdebatan yang disepakati, minimal mengurangi kesenjangan perdebatan. Deliberatif artinya harus bercorak partisipatif.

Cendekiawan (menggunakan bahasa Sudjatmoko) harus terjun langsung ke lapangan praktis untuk mengubah situasi. Ini sejalan dengan gagasan Purwo Santoso bahwa perjuangan demokratis harus pertama-tama bercorak activis based. Sudjatmoko menyitir pendapat para filsuf kecurigaan yang mengatakan bahwa seorang cendekiawan tidak boleh hanya mendaku, mandiri, dan kritis, namun tidak berakar pada konteks sosial dan budaya sehingga jiwa keprihatinannya tidak terartikulasi dengan tegas. Seorang cendekiawan harus terlibat jika mau merubah dunia. ${ }^{20}$

Sederhananya, seorang cendekiawan tidak boleh hanya sekedar memerankan fungsi sebagai ilmuwan yang berdiri di menara gading. Seorang cendekiawan harus mampu dan mau secara langsung terlibat dalam proses sosial. Janganlah seorang cendekiawan hanya berkutat dalam aktivitas semu di tataran ideologi, memerankan fungsi berkhotbah semata. Seorang cendekiawan harus mampu berdiri di dua dunia, dunia pemikiran dan dunia praktis.

\footnotetext{
${ }^{19}$ Sunarko, 2010.

${ }^{20}$ Sartre, Foucault, Bourdieu, Gramsci, dalam Haryatmoko, 2010.
} 


\section{Penutup}

Demokrasi dicirikan dengan empat karakteristik dasar, yakni partisipasi, kontestasi, kompetisi, dan liberalisasi. Empat fundamen dasar ini harus diperjuangkan. Itulah sebabnya, istilah demokratisasi merujuk pada term perjuangan mewujudkan demokrasi. Sejatinya, seorang cendekiawan harus tegas memahamkan diri dalam dunia yang nyata, yakni dunia pemikiran dan dunia praktis. Seorang cendekiawan idealnya terlibat dalam proses-proses yang mampu menggiring publik masuk dalam ranah demokrasi, minimal dalam tataran demokratisasi. Dengan cara ini, tahapan konsolidasi demokrasi akan terakselerasi.

\section{Referensi:}

Diamond, Larry, 2003. Developing Democracy Toward Consolidation, diterjemahkan oleh Tim IRE Yogyakarta, IRE Press Yogyakarta, Yogyakarta.

Haryatmoko, 2010. Dari Pewaris Filsafat Kecurigaan ke Soedjatmoko, dalam Majalah Basis Nomor 07-08, Tahun ke-59, 2010. Jakarta.

Ketchum, Richard M., 2004. Demokrasi Sebuah Pengantar, diterjemahkan oleh Mukhtasar, Niagara, Yogyakarta.

Purwo Santoso, 2009. Kekuasaan, Kesejahteraan, dan Demokrasi, Makalah yang disampaikan dalam Intensive Course and Training on Human Right-Based Democracy 2009: Power, Welfare, and Democracy, Yogyakarta, 13-18 Desember 2009.

Purwo Santoso, 2010. Dialog Jakarta-Papua: Sebuah Keniscayaan?, Makalah Seminar yang Disampaikan pada Seminar diselenggarakan oleh Imparsial, Yogyakarta, 21 Oktober 2010.

Sorensen, Georg, 2003. Demokrasi dan Demokratisasi (Proses dan Prospek dalam Sebuah Dunia yang Sedang Berubah), dialihbahasakan oleh I. Made Krisna, Pustaka Pelajar, Yogyakarta. 
Sunarko, 2010. Ruang Publik dan Agama Menurut Habermas dalam Ruang Publik Melacak 'Partisipasi Demokratis' dari Polis Sampe Cyberspace, editor F.X. Budi Hardiman, Kanisius, Yogyakarta.

Urofsky, Melvin I., 2002. Prinsip-Prinsip Dasar Demokrasi dalam Politik, Demokrasi, \& Manajemen Komunikasi, Galang Press, Yogyakarta.

Tornquist, Olle \& Nicolaas Warouw, 2009. Memahami Demokrasi: Beberapa Catatan Pendahuluan tentang Konsep dan Metode dalam Demokrasi di Atas Pasir, editor Willy Purna Samdhi \& Nicolaas Warouw, Demos, Jakarta. 